\section{Health inequalities based on ethnicity in individuals aged 15 to 64, Brazil, 1998}

\author{
Desigualdades de saúde segundo cor em pessoas \\ de 15 a 64 anos de idade no Brasil, 1998
}

\author{
${ }^{1}$ Faculdade de Ciências \\ Médicas, Santa Casa de \\ São Paulo, São Paulo, Brasil. \\ 2 Faculdade de Saúde \\ Pública, Universidade de \\ São Paulo, São Paulo, Brasil. \\ 3 Centro de Vigilância \\ Epidemiológica Prof. \\ Alexandre Vranjac, \\ São Paulo, Brasil. \\ ${ }^{4}$ Fundação Sistema \\ Estadual de Análise \\ de Dados, \\ São Paulo, Brasil. \\ Correspondence \\ R. B. Barata \\ Departamento de \\ Medicina Social, Faculdade \\ de Ciências Médicas, Santa \\ Casa de São Paulo. \\ Rua Dr. Cesário Motta Jr. \\ 61, 5o andar, São Paulo, SP \\ 01221-020, Brasil. \\ rita.barata@fcmscs.edu.br
}

\begin{abstract}
This study aimed to analyze inequalities in health status and utilization of medical consultations and hospital services by Brazilian young and adult populations according to ethnicity. The survey analyzes a representative sample of the Brazilian population aged 15 to 64 years, except those living in the rural area of the Amazon. The prevalence of fair or poor health status was substantially higher among black men, white women, and black women. The influence of gender and ethnicity remains significant after adjusting for age and socioeconomic conditions $(O R=1.11 ; 1.49$ and 1.86 respectively). Differences between blacks and whites decrease with age, but increase with socioeconomic status. There were 10\% more medical consultations among white individuals. The differences were more striking among young people who reported good health status. For individuals with fair or poor health, no differences were observed in frequency of medical consultations between blacks and whites. There were no significant differences in hospitalization rates. With regard to health status, differences between blacks and whites were striking. However, the same was not true for utilization of health services.
\end{abstract}

Health Inequalites; Gender; Race; Ethnic Groups
Rita Barradas Barata ${ }^{1}$

Márcia Furquim de Almeida 2

Cláudia Valencia Montero 3

Zilda Pereira da Silva 4

\section{Introduction}

Equity in health may be defined as the absence of unfair inequalities, or for operational purposes, as the absence of systematic inequalities between groups with different social positions due to different levels of wealth, power, and prestige 1 .

The concept of equity is inherently normative, whereas inequality may denote only a difference, without any connotation of injustice. The central idea in the concept of equity can be expressed as equal opportunities to be and remain healthy and is rooted in the right to health. It also includes the right to decent living standards, as well as other human rights, such freedom from discrimination and the ability to fully participate in community life (social inclusion). Health inequality is unfair if it is systematically associated with social disadvantages in such a way that the social groups that are already penalized because of their socioeconomic status suffer further disadvantages in the promotion, protection, and recovery of their health 1 .

The usual explanation for health inequalities has been that one's lifestyle is the expression of individual choices and behaviors that can either reinforce or jeopardize health. However, the control of such variables cannot suppress some differentials 2 . Health inequalities always reflect social determinants, there is usually no specificity between particular causes and outcomes, 
and they rarely disappear as a result of individual medical action 3 .

In her echo-social theory, Krieger ${ }^{4}$ postulates that throughout their lives, individuals biologically incorporate the social experiences resulting from their lifestyles and express this incorporation in standards of health, disease, and well-being. On the one hand, the critical determinants of this process relate to the social arrangements of power and property and to the contingent standards of production and consumption that are associated with them. On the other, they also relate to the limits and possibilities of our bodies, shaped by the human species' evolutionary history and ecological context, as well as individual paths of biological and social development.

Krieger 5 contends that researching health inequalities according to race/ethnicity was among the core issues of the $20^{\text {th }}$ century and should remain so for research in the current century. Understanding race as a genetically-based biological construct, although scientifically disregarded since the 1970s, remains a valid explanation for health inequalities according to many researchers 6 .

Likewise, the socio-anthropological explanation, based on the purported cultural, moral, and economic inferiority of some ethnic groups, employed to sustain racist positions, still underlies the position of intellectuals that attribute differences between ethnicities to a sum of personal irresponsibility and introjection of dependence $5,7,8$.

Although (from a historical perspective) ethnic and gender disparities have sometimes been attributed to biological factors (racist or sexist theories) and sometimes to socioeconomic factors (economicist theories), the complex mechanisms by which social advantages and disadvantages operate on health are still insufficiently known 9

However, there is empirical evidence that uneven social relations, characterized by discrimination, exclusion, and exploration, have profound effects on the well-being of social groups and may be expressed in health inequalities. Ethnic minorities are inserted differently in society's production and consumption structure 10,11.

In Brazil, the Unified National Health System (SUS), organized in 1990 following approval of the new Federal Constitution in 1988, established universality, comprehensiveness, and equity in the access to and utilization of health services as fundamental principles and a means for guaranteeing the right to health set forth in the Constitution. Access to health services is considered a right of all citizens, not conditioned on social security payments. However, health inequalities persist due to differences in living conditions and services availability 12 .

This paper aims to analyze inequalities in health status and utilization of services by young and adult populations (15 to 64 years of age), based on ethnicity, after stratification by age and socioeconomic status.

\section{Methods}

Data in this analysis were compiled as part of the health supplement of the National Household Sample Survey (PNAD) conducted in 1998 by the Instituto Brasileiro de Geografia e Estatística, or National Census Bureau (IBGE), with funding by the Ministry of Health. The multiple-stage sample provides representative information on the Brazilian population, except for the rural population of the Northern region. The survey included 221,020 individuals ranging from 15 to 64 years of age.

The analysis used outcome variables like selfassessed health status, with the five original options grouped into only two: good versus and fair or poor health status, medical consultations, and hospitalizations in the previous 12 months.

Predisposing variables for health services utilization included: age, gender, self-defined ethnicity, monthly family income in multiples of the minimum wage as an indicator of purchasing power, and schooling as an indicator of social status.

Two complementary techniques were used to analyze data: stratified analysis by age, income, and schooling for the comparison between ethnicities, and non-conditional logistic regression including all variables in the model, since they all showed significant associations with outcomes in the univariate analysis.

For the purposes of this paper, ethnicity was defined as the "shared set of myths, ancestors, religion, territory, language, memories of a collective past, eating habits, and clothing that regulate the relations of a human community" 13 (p. 5). Respondents' self-reported color was used as the proxy for ethnicity 14,15 . For the analysis, mulattos were grouped with blacks. Asian and indigenous individuals were not included in the analysis.

To assess the effect of ethnicity, the authors chose to create a combined variable including ethnicity and gender, since women showed worse health status in practically all the populations studied. A total of 212,337 individuals were included in the analysis. There was a loss of $4 \%$ in the initial sample due to lack of information on one or more target variables. 
Given that the population's health status and health services utilization are contingencies that depend more on a set of interrelated variables than the sum of independent factors, adjustment models could hide some relevant aspects. Some factors may have different relations in different strata, and such effects are difficult to identify in regression models. Stratification may help clarify related processes without requiring a large number of assumptions 9. Prevalence ratios were calculated for each stratum and also for the whole using the Mantel-Haenszel procedure. Confidence intervals were calculated using the Taylor series, with a 95\% level. Epi Info 6.10 (Centers for Disease Control and Prevention, Atlanta, USA), SPSS 11.0 (SPSS Inc., Chicago, USA), and Stata 6.0 (Stata Corp., College Station, USA) were used for data processing.

Since socioeconomic disadvantages may largely explain health status and the health services utilization patterns by ethnic minorities, the authors chose to control for the effect of monthly family income and schooling on outcomes, thus aiming to highlight the mediating character of such variables on the modeling of social inequalities in health.

\section{Health status}

Among interviewees, $4.92 \%$ considered their health poor, $21.85 \%$ fair, and $73.23 \%$ good. Blacks were more likely to report fair or poor health as compared to whites (RP $=1.19$; 95\%CI:1.181.21).

Univariate analysis showed an association between all social and demographic variables and prevalence of fair or poor health (data not shown). In terms of ethnicity, self-reported fair or poor health was lowest among white males (17.85\%), followed by black males (21.96\%), white females (24.28\%), and black females (31.4\%).
Adjustment by age, schooling, and income through non-conditional logistic regression reduced the odds ratios without eliminating the effect of ethnicity. Considering only the compound variable gender/ethnicity, black men had a $23 \%$ higher prevalence of fair or poor health than white men. This difference increased to $45 \%$ after adjusting for age and decreased to $16 \%$ after adjusting for schooling and $11 \%$ after adjusting for family income, thus suggesting that a considerable part of the health difference between white and black men was due to socioeconomic status.

For white women compared to white men, the overall difference of $36 \%$ increased to $46 \%$ after adjusting for age, to $50 \%$ for schooling, and to $49 \%$ for family income, stressing the importance of the gender variable in determining self-perceived health status.

Black women, who showed a higher risk of fair or poor health in the univariate analysis as compared to white men, continued at increased risk after adjusting for all variables. After adjusting for age, the relative risk increased, reaching $133 \%$ $(\mathrm{OR}=2.33)$. The odds ratio dropped to 1.97 after controlling for schooling. Controlling for family income resulted in an OR of 1.86 (Table 1).

Part of the excess risk may be attributed to the female gender, as observed for white women. If black women had the same risk as white women, after adjusting for age, family income, and schooling, the risk should be equal to 1.49 . Therefore, there was an excess risk of $24.83 \%$ among black women, suggesting other social, economic, and cultural factors not controlled for in the analysis.

Therefore, contrary to the observation for black men, controlling for age, schooling, and family income for black women was not sufficient to reduce the risk of fair or poor health status.

Various studies on ethnic and health inequalities have shown that even after adjusting for so-

Table 1

Overall and adjusted odds ratios and confidence intervals for prevalence of fair or poor health status according to gender and ethnicity. Brazil, 1998.

\begin{tabular}{lcccc}
\hline \multicolumn{1}{c}{ Variable } & Overall OR & Age OR & $\begin{array}{c}\text { Age/Schooling } \\
\text { OR }\end{array}$ & $\begin{array}{c}\text { Age/Schooling/ } \\
\text { Income OR }\end{array}$ \\
\hline White males & 1.00 & 1.00 & 1.00 & 1.00 \\
Black males & $1.23(1.20-1.26)$ & $1.45(1.40-1.50)$ & $1.16(1.13-1.20)$ & $1.11(1.07-1.14)$ \\
White females & $1.36(1.33-1.39)$ & $1.46(1.42-1.51)$ & $1.50(1.46-1.55)$ & $1.49(1.45-1.54)$ \\
Black females & $1.76(1.72-1.80)$ & $2.33(2.26-2.40)$ & $1.97(1.91-2.04)$ & $1.86(1.80-1.92)$ \\
\hline
\end{tabular}


cioeconomic variables such as income, education, occupation, and job position, the differences remain between whites and blacks 10,16,17,18,19. Standardization by socioeconomic variables for comparing ethnic groups may lead to the assumption that all factors were controlled for and that there are no other residual confounding factors 8

The relative difference in the prevalence of fair or poor health according to ethnicity was the same in all family income strata in the 15-24-year age group, with figures near the overall value except for the income bracket above 5 times the minimum wage (Table 2). In the 25-44 and 45-64year groups, the differences were not significant in the first two family income brackets, suggesting that economic deprivation in these groups, along with increasing age and health problems, eventually eliminated the differences between ethnicities. In the family income bracket from 3 to 5 times the minimum wage, the difference between whites and blacks became significant again; in the family income bracket above 5 times the minimum wage, it reached maximum values for all ages. This inconsistent aspect (greater inequality in higher incomes groups, regardless of age) suggests that inequalities between white and black individuals extended beyond income differences, probably reflecting the consequences of existing discrimination in Brazilian society.

The stratified analysis for education showed relative differences similar to the overall figures for the first three ranges of education among young people. For young adults and adults with up to 3 years of schooling, there was no difference between whites and blacks in the prevalence of fair or poor health. The differences were significant as of the 4-7 years of schooling group, and continued to increase with schooling. The distribution nearly repeated the same pattern observed in stratification by family income, again showing the more pronounced differences between individuals with better socioeconomic status (Table 3).

Nazroo ${ }^{8}$ reports higher prevalence of fair or poor health among individuals who report having experienced prejudice and discrimination in the previous year. The risk was increased for those who reported physical abuse due to discriminatory behavior $(\mathrm{OR}=2.07)$, but also for those reporting only verbal abuse $(\mathrm{OR}=1.54)$ as compared to those who did not report experiencing any kind of ethnic prejudice. Likewise, the risk was higher among individuals who perceived the community in which they lived as prejudiced $(\mathrm{OR}=1.39)$

If ethnic groups are viewed as historically determined social constructs, then economic, social, cultural, and political processes are complexly related to the development of ethnicities, with impacts on health. Socioeconomic indicators are relatively poor markers of social circumstances that can have different meanings for different ethnic groups. Social disadvantages and exclusionary practices affect each other mutually and cannot be easily separated. Moreover, largescale social determinants cannot be assessed by simple individual measurements 20,21.

\section{Health services utilization}

Health services utilization, assessed by the report of at least one medical consultation in the previous 12 months or hospitalization in the previous year, was inversely proportional to health status. Frequency of medical consultations in the previous year among whites was $10 \%$ higher than among blacks (95\%CI: 1.09-1.10). No significant differences were seen in hospital admissions.

\section{Medical consultations}

Medical consultations increased with age in both whites and blacks. Both ethnic groups tended to have constant rates in the first three family income brackets, and there was an increase in the rates among the wealthier. Inequalities between whites and blacks in frequency of medical visits may be considered negligible. All ratios showed estimates below the overall figures, suggesting that inequalities between whites and blacks tend to decrease after controlling for age and family income (Table 4).

In both whites and blacks, frequency of medical visits was higher among individuals who reported fair or poor health for all ages and income levels.

In young people (15-24 years), there was a higher frequency of medical visits among whites with good health, regardless of income. These differences may be associated with more frequent preventive checkups by white youth. For youth reporting fair or poor health, there was practically no difference between the two groups in frequency of medical visits. Thus, there is apparently no major difference in access to medical visits when health problems exist. The data do not allow inferring the number or quality of medical consultations.

A similar pattern was seen in the remaining age groups, but with lower relative values than among young people, and only significant in the higher-income brackets, thus reinforcing the assumption that whites use more medical checkups, since the differences only occurred for those 
Prevalence of fair or poor health status according to age, family income, and ethnicity. Brazil, 1998.

\begin{tabular}{|c|c|c|c|c|c|c|c|c|c|c|}
\hline \multirow{3}{*}{$\begin{array}{l}\text { Family income } \\
\text { (times minimum } \\
\text { wage) }\end{array}$} & \multirow[t]{3}{*}{ Ethnicity } & \multicolumn{9}{|c|}{ Age (years) } \\
\hline & & \multicolumn{3}{|c|}{$15-24$} & \multicolumn{3}{|c|}{$25-44$} & \multicolumn{3}{|c|}{$45-64$} \\
\hline & & Prevalence & OR & $95 \% \mathrm{Cl}$ & Prevalence & OR & $95 \% \mathrm{Cl}$ & Prevalence & OR & $95 \% \mathrm{Cl}$ \\
\hline \multirow[t]{2}{*}{$<1$} & White & 13.29 & & & 29.07 & & & 64.36 & & \\
\hline & Black & 16.06 & 1.21 & $1.07-1.36$ & 32.57 & 1.00 & & 59.88 & 1.00 & \\
\hline \multirow[t]{2}{*}{$1-2$} & White & 13.71 & & & 27.32 & & & 55.09 & & \\
\hline & Black & 16.33 & 1.19 & $1.08-1.32$ & 28.56 & 1.00 & & 56.24 & 1.00 & \\
\hline \multirow[t]{2}{*}{$3-5$} & White & 11.18 & & & 21.6 & & & 49.37 & & \\
\hline & Black & 12.84 & 1.18 & $1.09-1.27$ & 25.91 & 1.20 & $1.15-1.25$ & 52.03 & 1.05 & $1.02-1.09$ \\
\hline \multirow[t]{2}{*}{$>5$} & White & 6.24 & & & 12.47 & & & 30.54 & & \\
\hline & Black & 9.53 & 1.47 & $1.35-1.60$ & 18.04 & 1.45 & $1.38-1.52$ & 40.62 & 1.33 & $1.28-1.38$ \\
\hline
\end{tabular}

Table 3

Prevalence of fair or poor health status according to age, schooling, and ethnicity. Brazil, 1998.

\begin{tabular}{|c|c|c|c|c|c|c|c|c|c|c|}
\hline \multirow{3}{*}{$\begin{array}{l}\text { Schooling } \\
\text { (years) }\end{array}$} & \multirow[t]{3}{*}{ Ethnicity } & \multicolumn{9}{|c|}{ Age (years) } \\
\hline & & \multicolumn{3}{|c|}{$15-24$} & \multicolumn{3}{|c|}{$25-44$} & \multicolumn{3}{|c|}{$45-64$} \\
\hline & & Prevalence & OR & $95 \% \mathrm{Cl}$ & Prevalence & OR & $95 \% \mathrm{Cl}$ & Prevalence & OR & $95 \% \mathrm{Cl}$ \\
\hline \multirow[t]{2}{*}{$\leq 3$} & White & 15.86 & & & 30.95 & & & 55.38 & & \\
\hline & Black & 15.40 & 1.21 & $1.07-1.36$ & 31.82 & 1.00 & & 56.07 & 1.00 & \\
\hline \multirow[t]{2}{*}{$4-7$} & White & 10.74 & & & 22.42 & & & 41.85 & & \\
\hline & Black & 13.15 & 1.19 & $1.08-1.32$ & 25.31 & 1.13 & $1.09-1.17$ & 46.92 & 1.10 & $1.06-1.14$ \\
\hline \multirow[t]{2}{*}{$8-10$} & White & 7.54 & & & 15.76 & & & 32.20 & & \\
\hline & Black & 11.38 & 1.18 & $1.09-1.27$ & 21.25 & 1.35 & $1.26-1.44$ & 38.36 & 1.19 & $1.10-1.29$ \\
\hline \multirow[t]{2}{*}{$\geq 11$} & White & 6.16 & & & 9.31 & & & 19.42 & & \\
\hline & Black & 10.18 & 1.47 & $1.35-1.60$ & 15.44 & 1.66 & $1.55-1.77$ & 29.20 & 1.50 & $1.39-1.63$ \\
\hline
\end{tabular}

who reported good health status and those with higher family income ( $>5$ times the minimum wage).

Parkerson et al. 22, studying the utilization of primary care services in rural North Carolina, found a higher proportion of blacks than whites with at least one medical visit in an 18-month follow-up. Other predictors of services utilization were: age, gender, number of health problems, self-assessed health status, and severity of problems. However, referrals and follow-up appointments were more common among whites.
Similar results were obtained in a study on the clientele of general practitioners in the UK National Health System, where individuals born in India, Pakistan, and Bangladesh visited physicians more frequently, probably reflecting greater need 23.

In Brazil, the SUS appears to ensure access to physician visits, especially when health problems exist (fair or poor self-perceived health), regardless of ethnicity and family income. Among individuals with good self-perceived health, there are differences favoring white and higher-income 
Medical consultations according to age group, health status, monthly family income, and ethnicity. Brazil, 1998.

\begin{tabular}{|c|c|c|c|c|c|c|c|}
\hline & \multirow[t]{3}{*}{ Ethnicity } & \multicolumn{6}{|c|}{ Health status } \\
\hline & & \multicolumn{3}{|c|}{ Good } & \multicolumn{3}{|c|}{ Fair and poor } \\
\hline & & Frequency & OR & $95 \% \mathrm{Cl}$ & Frequency & OR & $95 \% \mathrm{Cl}$ \\
\hline \multicolumn{8}{|c|}{$15-24$ years } \\
\hline \multicolumn{8}{|c|}{ Family income (times minimum wage) } \\
\hline \multirow[t]{2}{*}{$\leq 2$} & White & 43.49 & 1.08 & $1.04-1.12$ & 70.15 & 1.00 & \\
\hline & Black & 40.23 & & & 66.33 & & \\
\hline \multirow[t]{2}{*}{$2-5$} & White & 41.42 & 1.13 & $1.09-1.17$ & 70.94 & 1.08 & $1.02-1.13$ \\
\hline & Black & 36.79 & & & 65.92 & & \\
\hline \multirow[t]{2}{*}{$5-10$} & White & 44.38 & 1.11 & $1.06-1.15$ & 71.41 & 1.00 & \\
\hline & Black & 40.14 & & & 69.07 & & \\
\hline \multirow[t]{2}{*}{$10-20$} & White & 50.28 & 1.14 & $1.08-1.21$ & 77.78 & 1.00 & \\
\hline & Black & 44.06 & & & 76.06 & & \\
\hline \multirow[t]{2}{*}{$>20$} & White & 58.70 & 1.11 & $1.03-1.19$ & 79.65 & 1.00 & \\
\hline & Black & 53.07 & & & 77.55 & & \\
\hline \multicolumn{8}{|c|}{$25-44$ years } \\
\hline \multicolumn{8}{|c|}{ Family income (times minimum wage) } \\
\hline \multirow[t]{2}{*}{$\leq 2$} & White & 44.85 & 1.00 & & 70.27 & 1.00 & \\
\hline & Black & 43.38 & & & 69.72 & & \\
\hline \multirow[t]{2}{*}{$2-5$} & White & 48.94 & 1.00 & & 75.10 & 1.04 & $1.02-1.07$ \\
\hline & Black & 47.50 & & & 71.92 & & \\
\hline \multirow[t]{2}{*}{$5-10$} & White & 55.19 & 1.04 & $1.01-1.07$ & 78.02 & 1.00 & \\
\hline & Black & 53.18 & & & 76.21 & & \\
\hline \multirow[t]{2}{*}{$10-20$} & White & 60.46 & 1.05 & $1.02-1.09$ & 80.42 & 1.00 & \\
\hline & Black & 57.45 & & & 82.41 & & \\
\hline \multirow[t]{2}{*}{$>20$} & White & 67.94 & 1.08 & $1.03-1.13$ & 83.62 & 1.00 & \\
\hline & Black & 62.96 & & & 82.05 & & \\
\hline \multicolumn{8}{|c|}{$45-64$ years } \\
\hline \multicolumn{8}{|c|}{ Family income (times minimum wage) } \\
\hline \multirow[t]{2}{*}{$\leq 2$} & White & 45.56 & 1.00 & & 75.22 & 1.05 & $1.02-1.08$ \\
\hline & Black & 43.39 & & & 71.63 & & \\
\hline \multirow[t]{2}{*}{$2-5$} & White & 49.43 & 1.00 & & 77.90 & 1.00 & \\
\hline & Black & 47.13 & & & 75.92 & & \\
\hline \multirow[t]{2}{*}{$5-10$} & White & 56.92 & 1.09 & $1.04-1.14$ & 81.97 & 1.00 & \\
\hline & Black & 52.39 & & & 80.69 & & \\
\hline \multirow[t]{2}{*}{$10-20$} & White & 64.13 & 1.07 & $1.02-1.13$ & 84.23 & 1.00 & \\
\hline & Black & 59.98 & & & 82.27 & & \\
\hline \multirow[t]{2}{*}{$>20$} & White & 73.00 & 1.08 & $1.02-1.15$ & 86.50 & 1.00 & \\
\hline & Black & 67.30 & & & 83.04 & & \\
\hline
\end{tabular}

individuals, suggesting that preventive medical checkups are distributed more unequally than treatment appointments, or that there are important cultural differences between whites and blacks.

The results for education were very similar to those of family income. Again, adjustment for one socioeconomic variable reduces the previously observed inequality (data not shown).

By adjusting the data according to health status, there were no differences in the use of medical consultations between whites and blacks for any schooling level or age group, among individuals with fair or poor health. Thus, the chief 
Utilization of inpatient units in the previous year according to age, family income, and ethnicity. Brazil, 1998.

\begin{tabular}{|c|c|c|c|c|c|c|c|c|}
\hline \multirow{3}{*}{$\begin{array}{l}\text { Family income } \\
\text { (times minimum } \\
\text { wage) }\end{array}$} & \multirow[t]{3}{*}{ Ethnicity } & \multicolumn{7}{|c|}{ Age (years) } \\
\hline & & \multicolumn{3}{|c|}{$15-24$} & \multicolumn{2}{|c|}{$25-44$} & \multicolumn{2}{|c|}{$45-64$} \\
\hline & & Frequency & OR & $95 \% \mathrm{Cl}$ & Frequency & OR & Frequency & OR \\
\hline \multirow[t]{2}{*}{$<1$} & White & 4.25 & 1.00 & & 6.02 & 1.00 & 10.61 & 1.00 \\
\hline & Black & 3.37 & & & 6.68 & & 10.34 & \\
\hline \multirow[t]{2}{*}{$1-2$} & White & 4.04 & 1.00 & & 5.93 & 1.00 & 9.78 & 1.00 \\
\hline & Black & 3.93 & & & 5.88 & & 9.61 & \\
\hline \multirow[t]{2}{*}{$3-5$} & White & 3.36 & 1.00 & & 4.68 & 1.00 & 8.66 & 1.00 \\
\hline & Black & 3.03 & & & 4.70 & & 8.24 & \\
\hline \multirow[t]{2}{*}{$>5$} & White & 3.07 & 1.23 & $1.06-1.43$ & 4.69 & 1.00 & 7.52 & 1.00 \\
\hline & Black & 2.86 & & & 4.84 & & 7.64 & \\
\hline
\end{tabular}

determinants of utilization are actual health needs. Individuals with good health were slightly more likely to have used medical consultations in the previous 12 months, favoring whites. Among young people (15-24 years), there was a larger difference between individuals with up to 3 years of schooling, while in the other schooling brackets the difference between ethnic groups remained constant. For young adults and adults, there was practically no difference according to level of schooling.

Again, the data appear to suggest a higher proportional frequency of medical visits among healthy whites as compared to healthy blacks, and a similar frequency in the presence of perceived health problems.

\section{Hospitalizations}

For whites and blacks, hospitalization rates increased with age and decreased with family income. In each family income bracket, for all ages analyzed, no significant differences were observed between hospitalization rates for whites and blacks. The only exception was in the 1524-year group, for family income greater than 5 times the minimum wage. The rates ratio was 1.23 , but the confidence interval was wide (1.061.43) (Table 5).

The stratified analysis by schooling provided similar information. The comparison between whites and blacks did not show any statistically significant differences according to age group or schooling, except for young people with less schooling. For individuals 15 to 24 years of age, there were $26 \%$ more hospitalizations among whites; however, the confidence interval was wide, indicating the low accuracy of the estimate (data not shown).

The differences in hospitalization rates reflect a higher probability of hospitalization for groups with less schooling, regardless of ethnicity, suggesting that the main determinants of hospitalization were actual health needs. These data appear to contradict the findings for family income brackets, unless a considerable percentage of individuals with less education belong to the higher family income bracket ( $>5$ times the minimum wage) at different proportions according to ethnicity.

Generally speaking, the SUS appears to ensure equal access to hospitalization, since the observed admissions rates were directly proportional to health status and declined as socioeconomic status improved, with no significant difference between ethnic groups. However, the data do not allow inferences concerning hospitalization opportunities in relation to time between onset of illness and admission, or quality of care.

\section{Conclusions}

In the Brazilian population, differences between whites and blacks were more pronounced in relation to health status than to utilization of health services, probably reflecting poorer living conditions and greater difficulty by the black population in maintaining adequate health status. Such difficulties were partially offset by the universal access provided under the SUS. 
Controlling for individual socioeconomic variables such as mean monthly family income and educational level reduced the differences between whites and blacks, especially the frequency of medical consultations and hospitalizations. Equality in frequency tended to be greater for individuals with fair or poor health status, suggesting that health needs were more important determinants of health services utilization than individual socioeconomic status or ethnicity.

For those who reported good health status, differences between whites and blacks were greater in the frequency of medical consultations, suggesting differences in the utilization of preventive versus treatment procedures.

The Brazilian elite has drawn extensively on the myth of racial democracy in the country, denying the existence of any racial stratification on the grounds that Brazilians are the result of the racial union of whites, blacks, and indigenous peoples. According to this view, ideologically Brazilians are just Brazilians with different colors. It was not until the 1970s that demographic and socioeconomic information highlighted the great social inequalities between whites and blacks. Most of these differences are socioeconomic, making it difficult to distinguish to what extent they result from poverty as opposed to race-related social exclusion 24 .

Social discrimination manifests itself chiefly in social relations of domination and oppression. Socially discriminated groups generally accumulate disadvantages in many aspects (economic, social, ethnic, gender, and others). Dominant groups use practices and ideologies of subordination to justify notions of superiority/inferiority, difference, or deviation. Discrimination is characterized by different treatment for members of certain social groups simply on grounds of their belonging to such groups 4 .

The effects of discriminatory practices on health are modeled by individual features of reaction to the environment (which Americans call coping), by existing institutional relations in society, and by public policies (whether targeted to overcoming such effects or not), in addition to historical and macro-political determinants 25 .

Thus, ethnic issues can hardly be isolated from those resulting from individual social insertion, since ethnicity itself is the result of social construction. Attempts to isolate the effect of social and demographic variables to demonstrate whether differences remain which could be attributed to ethnicity will only make sense if understood as a methodological resource to guide public practices and policies aimed at eliminating discrimination, whether based on economic, educational, age-related, gender-based, or ethnic stratification.

For research purposes, separating health status, a result of multiple determinations in social groups' living conditions and habits, and health services utilization, partially conditioned by current public policies, emphasizes that social policies' potential compensatory effects may not be sufficient to completely offset the social inequalities resulting from differential insertion of various groups in society.

\section{Resumo}

O objetivo foi analisar desigualdades no estado de saúde, uso de consultas médicas e internações hospitalares na população de jovens e adultos brasileiros segundo cor utilizando dados do suplemento saúde da PNAD 1998, inquérito domiciliar em amostra representativa da população brasileira de 15 a 64 anos, exceto aqueles residentes na Amazônia rural. A prevalência de estado de saúde regular ou ruim foi mais alta entre homens e mulheres negros e mulheres brancas. A influência do gênero e da cor permanece significante após ajustamento por idade e condições sócio-econômicas. As diferenças entre brancos e negros diminuem com a idade e aumentam com o nível sócio-econômico. A freqüência de consultas médicas foi $10 \%$ maior entre os brancos. As diferenças são mais notáveis entre os jovens que referem bom estado de saúde. Não há diferença significante nas taxas de hospitalização. Em relação ao estado de saúde, as diferenças entre brancos e negros são marcantes. Entretanto, o mesmo não se observa para a utilização dos serviços de saúde.

Desigualdades em Saúde; Gênero; Raça; Grupos Étnicos 


\section{Contributors}

All the authors participated in the study design, discussion of the results, and manuscript review. R. B. Barata and M. F. Almeida were in charge of writing the paper. C. V. Montero and Z. P. Silva conducted the data processing.

\section{References}

1. Braveman P, Gruskin S. Defining equity in health. J Epidemiol Community Health 2003; 57:254-8.

2. Marmot M. Inequalities in health. N Engl J Med 2001; 345:134-6.

3. Marmot M. Epidemiology of socioeconomic status and health: are determinants within countries the same as between countries? Ann N Y Acad Sci 1999; 896:16-29.

4. Krieger N. Embodying inequality: a review of concepts, measures and methods for studying health consequences of discrimination. Int J Health Serv 1999; 29:295-352.

5. Krieger N. The ostrich, the albatross, and Public Health: an ecosocial perspective - or why an explicit focus on health consequences of discrimination and deprivation is vital for good science and public health practice. Public Health Rep 2001; 116:419-23.

6. Goodman AH. Why genes don't count (for racial differences in health). Am J Public Health 2000; 90:1699-702.

7. Krieger N. Counting accountably: implications of the new approaches to classifying race/ethnicity in the 2000 Census [Editorial]. Am J Public Health 2000; 90:1687-9.

8. Nazroo JY. The structuring of ethnic inequalities in health: economic position, racial discrimination and racism. Am J Public Health 2003; 93:277-84.

9. Cooper RS, Kennely JF, Durazo-Arvizu R, Oh HJ, Kaplan G, Lynch J. Relationship between premature mortality and socioeconomic factors in Black and White populations of US Metropolitan areas. Public Health Rep 2001; 116:464-73.

10. Cooper H. Investigating socio-economic explanations for gender and ethnic inequalities in health. Soc Sci Med 2002; 54:693-706.

11. Olinto MTA, Olinto BA. Raça e desigualdade entre as mulheres: um exemplo no sul do Brasil. Cad Saúde Pública 2000; 16:1137-42.

12. Travassos C, Viacava F, Pinheiro R, Brito A. Utilização dos serviços de saúde no Brasil: gênero, características familiares e condição social. Rev Panam Salud Pública 2002; 11:365-73.

13. Organização Pan-Americana da Saúde. Etnicidade e saúde. Tema 4.8 da Agenda Provisória. 132a Sessão do Comitê Executivo. Washington DC: Organização Pan-Americana da Saúde/Organização Mundial da Saúde; 2003.
14. Travassos C, Williams DR. The concept and measurement of race and their relationship to public health: a review focused on Brazil and the United States. Cad Saúde Pública 2004; 20:660-78.

15. Maio MC, Monteiro S, Chor D, Faerstein E, Lopes CS. Cor/raça no Estudo Pró-Saúde: resultados comparativos de dois métodos de autoclassificação no Rio de Janeiro, Brasil. Cad Saúde Pública 2005; 21:171-80.

16. Cooper RS. Social inequality, ethnicity and cardiovascular disease. Int J Epidemiol 2001; 30:548-52.

17. Levine RS, Foster JE, Fullilove RE, Fullilove MT, Briggs NC, Hull PC, et al. Black-white inequalities in mortality and life expectancy: 1933-1999: implications for Healthy People 2010. Public Health Rep 2001; 116:474-83.

18. Krieger N, Williams D. Changing to the 2000 standard million: are declining racial/ethnic and socioeconomic inequalities in health real progress or statistical illusion? Am J Public Health 2001; 91:1209-13.

19. Case A, Deaton A. Consumption, health, gender and poverty. Princeton: Center for Health and Well-being, Woodrow School, Princeton University; 2002.

20. Smith GD. Learning to live with complexity: ethnicity, socioeconomic position and health in Britain and United States. Am J Public Health 2000; 90:1694-8.

21. Chor D, Araujo CR. Aspectos epidemiológicos das desigualdades raciais em saúde no Brasil. Cad Saúde Pública 2005; 21:1586-94.

22. Parkerson GR, Broadhead WE, Tse CKJ. Health status and severity of illness as predictors of outcomes in primary care. Med Care 1995; 33:53-66.

23. Carr-Hill R, Rice N, Roland M. Socioeconomic determinants of rates of consultation in general practice based on fourth national morbidity survey of general practices. BMJ 1996; 312:1008-12.

24. Nobles M. History counts: a comparative analysis of racial/color categorization in US and Brazilian Censuses. Am J Public Health 2000; 90:1738-45.

25. McKenzie K. Racism and health. BMJ 2003; 326 : 65-6.

Submitted on 19/Apr/2005

Final version resubmitted on $05 / \mathrm{Dec} / 2005$ Approved on 10/Jan/2006 